\title{
Studenter i Norge lærer om sykepleiefaget i et internasjonalt perspektiv
}

Mange sykepleierstudenter har ikke praksisstudier i utlandet. Derfor er det viktig at utenlandske studenter i

Norge samarbeider og deler erfaringer med de hjemmehørende studentene.

\section{Lene Strøm}

Høgskolelektor

Institutt for helse- og omsorgsvitskap, Høgskulen på Vestlandet, campus Haugesund

\section{Kristin Ådnøy Eriksen}

Førsteamanuensis

Institutt for helse- og omsorgsvitskap, Høgskulen på Vestlandet, campus Haugesund

\section{Sigrund Breistig}

Høgskulelektor

Institutt for helse- og omsorgsvitskap, Høgskulen på Vestlandet, campus Stord

Utdanning Praksisstudier Internasjonalt samarbeid

\section{Hovedbudskap}


Internasjonalisering i sykepleierutdanningen er et krav fra norske og europeiske utdanningsmyndigheter. For å imøtekomme dette har vi videreutviklet en internasjonal tospannmodell i praksisstudiene. Det er en modell for undervisning der studenter lærer av og med hverandre uten direkte intervensjon fra en lærer. Erfaringene våre viser at noen av studentene har opplevd utfordringer med modellen.

I den nye rammeplanen for sykepleierutdanningen stilles det krav om at studenten skal kjenne til sykepleieutøvelse i et internasjonalt perspektiv (1). Det skal gjelde alle studenter, også dem som ikke reiser ut av Norge.

Også i den nye stortingsmeldingen for internasjonalisering i høyere utdanning (2) uttrykkes det en forventning om at utdanningsinstitusjonene skal skape en internasjonal dimensjon i utdanningen. Her fremkommer det også at mer enn 80 prosent av studentmassen aldri reiser på utveksling.

Det kan dermed lett oppstå sprik mellom myndighetenes krav og forventninger på den ene siden og utdanningsinstitusjonenes mulighet til å innfri disse på den andre. Derfor foreslås det i stortingsmeldingen at institusjonene må benytte seg av ressursen de internasjonale studentene representerer (2).

Ved sykepleierutdanningen i Haugesund hadde vi 45 internasjonale studenter i 2019. Vi etablerte en tospannmodell i praktiske studier bestående av en internasjonal og en hjemmehørende student. Studentene samarbeidet i par for å lære av og med hverandre.

I denne artikkelen vil vi dele studentenes erfaringer fra den internasjonale tospannmodellen. Vi har samlet data gjennom intervjuer og spørreskjemaer. Vi unders $\varnothing$ kte både de norske og de internasjonale studentenes erfaringer, men fokuserer på de norske studentenes opplevelse, som vi belyser med svar fra de internasjonale studentene. 


\section{Hva er en tospannmodell?}

En tospannmodell er en modell for undervisning og læringsstrategier der studenter lærer av og med hverandre, uten direkte intervensjon fra en lærer (3). Studentene rapporterer at de blir mer selvstendige, opplever økt kontroll og lærer av hverandre (4-7).

Modellen gjør at studentene utvikler sin relasjonskompetanse. I tillegg blir de mer effektive når de samarbeider på denne måten (6). Studentene kan oppleve tospannet som et trygt læringsrom.

Tospannet kan også bære med seg en konkurransefaktor ved at studentene noen ganger må konkurrere om relativt få arbeidsoppgaver og læresituasjoner, og at de føler at de må prestere for hverandre (8).

Studentene vektlegger betydningen av veiledning og tett oppfølging av kontaktsykepleieren $(4,5,7)$.

Samarbeidsmodellen legger til rette for læring i utvidet forstand fordi studentene utvikler seg ved å tilhøre en sosial kontekst av meningsskaping, kunnskap og samarbeid (9).

\section{«Studentene kan oppleve gjensidig læring når de samarbeider i praksis.»}

Erfaringer fra samarbeid mellom hjemmehørende og internasjonale studenter viser at studentene kan oppleve gjensidig læring når de samarbeider i praksis. Samarbeidet gir også $\varnothing \mathrm{kt}$ kulturell bevissthet og personlig og profesjonell utvikling (10-12).

Der studentene går i internasjonalt tospann, kjenner de hjemmehørende studentene seg myndiggjort og verdsatt som assisterende veiledere (10), og de føler et ansvar for de internasjonale studentene (11). 


\section{Hva gjorde vi i studien?}

Fra april til oktober 2019 gjennomførte 25 studentpar fem ukers praksis på tre omsorgssentre i Haugesund kommune. De internasjonale studentene var på tremåneders eller ett semesters utvekslingsopphold ved HVL, campus Haugesund.

Studentene som skulle delta i studien, fikk informasjon på forhånd om bakgrunnen for den internasjonale tospannmodellen og organiseringen av denne. Den første uken hadde studentparet tett kontakt med en kontaktsykepleier. Resten av perioden var det lagt opp til mer selvstendig studentsamarbeid.

Studentene og den veiledende sykepleieren hadde to daglige møter. Det første møtet gikk ut på å planlegge dagen, og i det andre ble læringsutbytter og faglige utfordringer gjennomgått. Studentene fikk veiledning ved behov og rapporterte ellers til sykepleieren i løpet av arbeidsdagen.

Midt- og sluttvurdering ble gjennomført individuelt for hver enkelt student. Studentene deltok i henholdsvis en norsk eller en engelsk praksisgruppe, men var også invitert i sin medstudents praksisgruppe.

\section{Etiske betraktninger}

Studien er vurdert av NSD med referansenummer 534479. Alle informantene har signert informert samtykke.

\section{Metode}

Totalt 23 studenter - 14 internasjonale og ni hjemmehørende - besvarte spørreskjemaet etter at de hadde gjennomført tospannpraksisen.

Studentene skulle beskrive fordeler og ulemper ved modellen, hva de lærte om sykepleie fra medstudentens hjemland, og om de utviklet sine kommunikasjonsferdigheter. Vi gjennomførte gruppeintervjuer med to norske studenter for å få mer utfyllende beskrivelser. 
Covid-19 satte en stopper for videre utprøving av den internasjonale tospannmodellen. Begrensede data gjør at studien metodisk ikke kvalifiserer for å være en vitenskapelig analyse. Likevel kan erfaringene gi indikasjoner for og retning til videre utforming og utvikling av praksismodellen.

Vi har gjort en enkel innholdsanalyse av studentenes skriftlige tilbakemeldinger fra spørreskjemaet. Data fra intervjuet er brukt til å underbygge disse.

\section{Resultater}

Erfaringene fra informantene ble kategorisert som «Skepsis til deltakelse», «Personlige læringsutbytter» og «Felles kontaktsykepleier - mindre oppfølging».

\section{Skepsis til deltakelse}

Av de ni norske studentene som deltok i studien, uttrykte åtte at de i utgangspunktet var negative til å delta i en internasjonal tospannmodell.

Skepsisen var knyttet til forventede språkutfordringer og tanken om at praksisformen ville gå på bekostning av deres egen læring. «Jeg fikk litt sjokk. Skal jeg ha praksis på engelsk!» (student $2 \mathrm{i}$ intervju). To av studentene skrev at de valgte bort utveksling i utlandet på grunn av språkutfordringer.

Etter å ha fullført praksisperioden meldte fire av ni studenter at de ville ha foretrukket en internasjonal tospannmodell en gang til. «Jeg tenkte at det kom til å bli utfordrende og kom til å gå utover min læring. Noe som det ikke gjorde, men heller motsatt» (student i spørreskjema).

\section{Personlige læringsutbytter}

Fire studenter opplevde tospannmodellen som en mulighet til refleksjon og faglig utvikling. Da studentene beskrev hva de lærte om sykepleie i et annet land, la de vekt på forskjellene i hvordan sykepleien var organisert. 
En student i intervju fortalte: «[I] Spania, der har ikkje sykepleierstudentane dei oppgåvene som me har, det er meir helsefagarbeidarane sin jobb slik som stell og løfteteknikkar [...]». Studentene fikk også innsikt i de formelle rammene rundt sykepleieryrket, som ansvarsområder, lønn og arbeidsforhold.

Både i spørreskjemaet og i intervjuet ble de internasjonale studentenes kunnskaper om prosedyrer og anatomi løftet frem: «De er gode på prosedyrer, mye fokus på dette, for eksempel blodprøvetaking» (student i spørreskjema).

Praksismodellen bidro til en følelse av $\varnothing \mathrm{kt}$ selvstendighet hos de hjemmehørende studentene. De opplevde å måtte ta ansvar for den internasjonale studentens læring.

\section{«Praksismodellen bidro til en følelse av $\emptyset \mathbf{k t}$ selvstendighet hos de hjemmehørende studentene.»}

Språkutfordringer gjorde at de norske studentene kjente seg forpliktet til å hjelpe sin internasjonale makker i pasientsamhandlingen. Flertallet av studentene forteller om språklig utvikling og vekst i sin kommunikasjonskompetanse.

Studentene beskrev utfordringer der den internasjonale studenten sto i bakgrunnen og den hjemmehørende ofte utførte arbeidsoppgavene: «De lærte mye av å se hvordan vi håndterte og utførte situasjoner» (student i spørreskjema).

En internasjonal student kommenterte det sånn: «[O]ur independence is reduced to basically following them around and listening to them talk to the patients» (internasjonal student). I slike situasjoner ble de norske studentene myndiggjort og plassert i en lederrolle. 


\section{Felles kontaktsykepleier - mindre oppfølging}

I spørreunders $\varnothing$ kelsen kommenterte fire av de norske studentene at de opplevde det som begrensende for læring å måtte dele kontaktsykepleier med den internasjonale studenten. Et eksempel var at prosedyrerelaterte læringssituasjoner måtte deles.

De internasjonale studentene opplevde også delingen som utfordrende: «Sometimes I felt they receive more attention from the mentor nurse because of the language. My mentor nurse often forget that I do not speak Norwegian, and I have the feeling that they teach more things to the Norwegian students» (internasjonal student i spørreskjema).

Dette medførte en følelse av eksklusjon og å være underordnet den norske studenten.

\section{Diskusjon}

Studentene skulle få en internasjonal dimensjon

Erfaringene fra studentene som deltok i den internasjonale tospannmodellen, spriker i mange retninger. Modellen var ment å gi de hjemmehørende studentene som ikke reiser på utveksling, en internasjonal dimensjon.

Myndighetene begrunner utvikling av internasjonal kompetanse i utdanningsløpet med betydningen det har å kunne være aktør i en global verden og samarbeide med mennesker fra andre kulturer (2).

Studentene i vår studie hadde ikke vist interesse for internasjonal utveksling. En del av dem var skeptiske til internasjonal samhandling på grunn av språklige utfordringer. Dette samsvarer med SSBs kartlegging av faktorer som gjør at studenter velger bort utveksling (13).

\section{«Til tross for at studentene i utgangspunktet var skeptiske, viser erfaringene i denne studien at de fikk økt sin interkulturelle kompetanse.»}


Spørsmålet er om vi skal tillate at sykepleierstudenter kan reservere seg fra læringsarenaer som gir interkulturell kompetanse. Kan en sykepleier reservere seg fra samhandling med en fremmedspråklig pasient?

Utdanningsinstitusjonene har et ansvar for å skape forståelse for at interkulturell kompetanse er en del av den profesjonelle kompetansen i dagens helsetjeneste.

I forskrift om nasjonal retningslinje for sykepleierutdanning (1) finner vi læringsutbyttebeskrivelsen, som sier at $\ll[\mathrm{k}]$ andidaten kjenner til globale helseutfordringer og sykepleieutøvelse i et internasjonalt perspektiv».

Til tross for at studentene i utgangspunktet var skeptiske, viser erfaringene i denne studien at de fikk $\varnothing \mathrm{kt}$ sin interkulturelle kompetanse. De har tatt ett skritt mot et internasjonalt perspektiv.

\section{Mange hadde personlig læringsutbytte}

Et betydelig læringsutbytte ved mobilitet er den personlige veksten man kan oppleve gjennom å kjenne på sin egen sårbarhet i møte med en ny kultur, språkutfordringer og å være i en uvant setting (14).

De norske studentene i vårt prosjekt kjente ikke på denne sårbarheten, men fikk likevel erfare ubehaget med språkutfordringer og det å måtte anstrenge seg for å ivareta den andres forståelse. Vi kan si at studentene utviklet generiske ferdigheter, noe som beskrives som ett av kjennetegnene ved kvalitet i høyere utdanning (15).

Dette innebærer at i tillegg til å lære kunnskap, ferdigheter og analytisk forståelsesramme som er spesifikk for sykepleierfaget, vil studentene utvikle sosiale og emosjonelle egenskaper, evne til selvrefleksjon og kreativ problemløsning gjennom denne internasjonale samarbeidsmodellen. 


\section{Internasjonal utveksling kan gi utrygghet}

Tospannmodellen i en internasjonal kontekst ser ut til å gi de hjemmeh $\varnothing$ rende studentene en opplevelse av å ha kontroll på læringsfeltet og sin kjernekompetanse. Dette er i tråd med tidligere forskning på tospannmodellen, som viser at studentenes opplevelse av kontroll fremmer læring (4).

Samtidig viser resultatene at modellen i dette tilfellet kan ha hatt motsatt effekt for de internasjonale studentene. De opplevde å stå i en underdanig posisjon, hvor selvstendigheten ble redusert, og de følte seg underordnet.

Heiberg, Dahl og Eriksen (14) forklarer dette med at internasjonal utveksling fører til en følelse av utrygghet i større eller mindre grad, da man er i en ny setting. Dette påvirket de norske studentenes læring. De følte et ansvar for å inkludere den internasjonale studenten i praksisarbeidet, og slik ble de utfordret til å se ut over sine egne behov.

\section{Felles kontaktsykepleier var en utfordring}

$\AA$ ha felles kontaktsykepleier skulle bidra til å forsterke studentene som par, samtidig som det var ment å være et ressursbesparende tiltak. I vår studie resulterte deling av kontaktsykepleier $i$ at studentene savnet kompetent faglig oppfølging.

I tillegg følte de hjemmehørende studentene et ansvar for å veilede de internasjonale. Det oppsto en del usikkerhet og ubehag knyttet til at den trygge og erfarne sykepleieren ble erstattet av en student. Boud, Cohen og Sampson (3) hevder at studenter kan ha en oppfatning om at formell opplæring skal være i regi av og utøves av lærere eller formelle veiledere.

\section{«Det oppsto en del usikkerhet og ubehag knyttet til at den trygge og erfarne sykepleieren ble erstattet av en student.»}


Studenter kan oppleve at det er vanskelig å akseptere at medstudenter kan ha noe å lære dem, eller at de selv har noe å lære bort. Som Boud, Cohen og Sampson sier: «[...] that it might be a situation where the ignorant lead the unknowing.»

I en slik situasjon er det av betydning å ta studentenes bekymringer på alvor og etablere en forståelse av hva denne læringsmodellen kan bidra til (3).

\section{Konklusjon}

Selv om omfanget av studentmobilitet $\varnothing$ ker betydelig $\mathrm{i}$ nær fremtid, vil det fremdeles være en stor andel av norske studenter som ikke kan benytte seg av denne muligheten i studieløpet sitt.

Det er derfor viktig at studieprogrammet som helhet har en internasjonal profil, og at de utenlandske studentene i Norge bidrar direkte til internasjonalisering av studiemiljøet gjennom samarbeid og erfaringsdeling med norske studenter (2).

HVL har en verdifull ressurs i våre internasjonale studenter; de er mange, og de er positive og velvillige til å inngå i prosjekter som kan inkludere dem i den norske utdanningsverdenen.

Studentene i vår studie oppgav også at de hadde gjennomgående positive erfaringer med denne praksisformen. Når det gjelder de hjemmehørende studentenes læringsutbytte, har studien gitt oss verdifull innsikt i deres mange og varierte opplevelser.

Om ikke alle erfaringene var udelt positive, ser vi verdien av å utvikle tilsvarende læringsmodeller for studenter som av ulike grunner ikke får mulighet til å dra ut i verden. De hjemmehørende studentene har, i tillegg til å oppnå obligatoriske læringsutbyttebeskrivelser, fătt en annerledes opplevelse. Det er en dimensjon de ellers ikke ville fătt i sine praksisstudier. 
Det er også påfallende at selv om de var skeptiske før oppstart, var det etter endt praksis flere studenter som ville ha foretrukket den samme modellen på nytt.

Vi anbefaler at videre forskning og utvikling legger vekt på hvordan de inkluderte studentene kan ivaretas og veiledes for å sikre gode læringsmuligheter og en aktiv studentrolle.

\section{Referanser}

1. Kunnskapsdepartementet. Forskrift om nasjonal retningslinje for sykepleierutdanning. Oslo: Kunnskapsdepartementet; 2019.

2. Meld. St. 7 (2O2O-2O21). En verden av muligheter - internasjonal studentmobilitet i høyere utdanning. Oslo: Kunnskapsdepartementet; 2021.

3. Boud D, Cohen R, Sampson J. Peer learning in higher education: learning from and with each other. Routledge; 2014.

4. Vae KJU, Vae KJ, Kvalevaag HK, Löfmark A. Nursing students' perceptions of peer learning as a learning model in clinical practice and students' learning through peer learning-an evaluation study. Nordisk tidsskrift for helseforskning. 2017;13(2).

5. Drange BB. Utprøving av tospann som veiledningsmodell. Uniped. 2013;36(03):46-59.

6. Pålsson Y, Mårtensson G, Swenne CL, Ädel E, Engström M. A peer learning intervention for nursing students in clinical practice education: a quasiexperimental study. Nurse Education Today. 2017;51:81-7.

7. Wareing M, Green H, Burden B, Burns S, Beckwith MA, Mhlanga F, et al. "Coaching and PeerAssisted Learning” (C-PAL) - The mental health nursing student experience: a qualitative evaluation. Journal of Psychiatric and Mental Health Nursing. 2018;25(8):486-95. 
8. Stenberg M, Carlson E. Swedish student nurses' perception of peer learning as an educational model during clinical practice in a hospital setting - an evaluation study. BMC Nursing. 2015;14(1):1-7.

9. Havnes A. Peer-mediated learning beyond the curriculum. Studies in Higher Education. 2008;33(2):193-204.

10. Gosse NL, Katic-Duffy A. Nursing student and faculty perceptions of reciprocity during international clinical learning experiences: a qualitative descriptive study. Nurse Education Today. 2020;84:104242.

11. Shields M, Quilty J, Dharamsi S, Drynan D. International fieldwork placements in low-income countries: exploring community perspectives. Australian Occupational Therapy Journal. 2016;63(5):321-8.

12. Mikkonen K, Elo S, Tuomikoski A-M, Kääriäinen M. Mentor experiences of international healthcare students' learning in a clinical environment: A systematic review. Nurse Education Today. 2016;40:8794.

13. AL Keute, K Steffensen, D Stenvoll. Hva hindrer studenter i å dra på utveksling? https://statbank.ssb.no/utdanning/artikler-og$\underline{\text { publikasjoner/studieopphold-i-utlandet }}$

14. Heiberg IG, Dahl H, Eriksen KÅ. How can studying abroad nurture nurse students' intelligent kindness? Nurse Education in Practice. 2019;41:102644.

15. Meld. St. 16 (2016-2017). Kultur for kvalitet i utdanningen. Oslo: Kunnskapsdepartementet; 2017. 